\title{
Seasonal dynamics of carbon and nutrients from two contrasting tropical floodplain systems in the Zambezi River basin
}

\author{
A. L. Zuijdgeest ${ }^{1,2}$, R. Zurbrügg ${ }^{1,2, a}$, N. Blank ${ }^{1,2, b}$, R. Fulcri ${ }^{1,2, c}$, D. B. Senn ${ }^{1,2,3}$, and B. Wehrli ${ }^{1,2}$ \\ ${ }^{1}$ Institute of Biogeochemistry and Pollutant Dynamics, ETH Zürich, Universitätstrasse 16, 8092 Zürich, Switzerland \\ ${ }^{2}$ Eawag: Swiss Federal Institute of Aquatic Science and Technology, Surface Waters - Research and Management, \\ Seestrasse 79, 6047 Kastanienbaum, Switzerland \\ ${ }^{3}$ San Francisco Estuary Institute, 4911 Central Avenue, Richmond, CA 94804, USA \\ anow at: F. Hoffmann-La Roche Ltd, Basel, Switzerland \\ ${ }^{b}$ now at: Departement Bau, Verkehr und Umwelt, Aarau, Switzerland \\ ${ }^{c}$ now at: Pro Natura Graubünden, Chur, Switzerland
}

Correspondence to: A. Zuijdgeest (alissa.zuijdgeest@usys.ethz.ch)

Received: 27 May 2015 - Published in Biogeosciences Discuss.: 9 July 2015

Revised: 3 December 2015 - Accepted: 11 December 2015 - Published: 21 December 2015

\begin{abstract}
Floodplains are important biogeochemical reactors during fluvial transport of carbon and nutrient species towards the oceans. In the tropics and subtropics, pronounced rainfall seasonality results in highly dynamic floodplain biogeochemistry. The massive construction of dams, however, has significantly altered the hydrography and chemical characteristics of many (sub)tropical rivers. In this study, we compare organic-matter and nutrient biogeochemistry of two large, contrasting floodplains in the Zambezi River basin in southern Africa: the Barotse Plains and the Kafue Flats. Both systems are of comparable size but differ in anthropogenic influence: while the Barotse Plains are still in large parts pristine, the Kafue Flats are bordered by two hydropower dams.

The two systems exhibit different flooding dynamics, with a larger contribution of floodplain-derived water in the Kafue Flats and a stronger peak flow in the Barotse Plains. Distinct seasonal differences have been observed in carbon and nutrient concentrations, loads, and export and retention behavior in both systems. The simultaneous retention of particulate carbon and nitrogen and the net export of dissolved organic and inorganic carbon and nitrogen suggested that degradation of particulate organic matter was the dominant process influencing the river biogeochemistry during the wet season in the Barotse Plains and during the dry season in the Kafue Flats. Reverse trends during the dry season indicated that primary production was important in the Barotse Plains, whereas the Kafue Flats seemed to have both primary production and res-
\end{abstract}

piration occurring during the wet season, potentially occurring spatially separated in the main channel and on the floodplain.

Carbon-to-nitrogen ratios of particulate organic matter showed that soil-derived material was dominant year-round in the Barotse Plains, whereas the Kafue Flats transported particulate organic matter that had been produced in the upstream reservoir during the wet season. Stable carbon isotopes suggested that inputs from the inundated floodplain to the particulate organic-matter pool were important during the wet season, whereas permanent vegetation contributed to the material transported during the dry season. This study revealed effects of dam construction on organic-matter and nutrient dynamics on the downstream floodplain that only become visible after longer periods, and it highlights how floodplains act as large biogeochemical reactors that can behave distinctly differently from the entire catchment.

\section{Introduction}

In current global budgets of organic matter and nutrients, large rivers (discharge $>400 \mathrm{~km}^{3} \mathrm{yr}^{-1}$ ) account for approximately $35 \%$ of the total freshwater-related flux to the ocean (Milliman and Farnsworth, 2011). In studies presenting global budgets and models for carbon, nitrogen, and phosphorus export via large rivers, tropical systems are of- 
ten underrepresented (Alvarez-Cobelas et al., 2008, 2009, 2012). Global extrapolations based on the well-studied temperate and boreal systems are therefore prone to large errors because they neglect the distinct seasonal flooding of extensive tropical floodplain areas (Junk, 1999; Junk et al., 1989). Floodplain systems have been recognized for their potential to alter fluxes of particulate matter, organic carbon, and nutrients transported by rivers (McJannet et al., 2012; Fisher and Acreman, 2004).

During transport from land to sea, riverine organic matter is modified by processes in biogeochemical reactors, specifically natural and artificial lakes and wetlands or floodplains. In the past decades, increasing energy demands have resulted in the construction of hydropower dams in most of the world's large river systems (Nilsson et al., 2005). These man-made biogeochemical reactors significantly change the characteristics of river flow. Since water flow is restricted in most lakes, particles have time to settle. The water exiting the lake is therefore depleted in particulate matter and its associated organic carbon and nutrients. Lake stratification favors hypoxia or anoxia in the hypolimnion, which can lead to methane outgassing (Barros et al., 2011; Bastviken et al., 2008; DelSontro et al., 2011), low oxygen concentrations, and potentially toxic levels of reduced substances in the outflow from turbines (Kunz et al., 2013). In addition to the direct effects of hydropower reservoirs, energy demands often require flow regimes that deviate from the natural tropical situation, changing the hydrography in the downstream reaches of the river (Lu and Siew, 2006; Maingi and Marsh, 2002; Rood et al., 2005).

Floodplains make up a large fraction of all tropical wetlands (which cover about 2.5-3.5\% of the Earth's surface), with areas of $>10^{6} \mathrm{~km}^{2}$ in South America and $>10^{5} \mathrm{~km}^{2}$ in Africa (Tockner and Stanford, 2002). Because of the large area, the periodic flooding and corresponding changing redox conditions, the high temperatures, and the intense rates of primary production (Junk and Piedade, 1993; Robertson et al., 1999; Ward and Stanford, 1995), the impact of tropical floodplains on riverine-transported organic matter and nutrients can be significant (Hamilton et al., 1997). Riverfloodplain exchange has been identified as a key process for the ecological and biogeochemical functioning in temperate (Hunsinger et al., 2010; Tockner et al., 2010) and tropical systems (e.g., Melack et al., 2009). Lateral exchange between a river and its floodplain was shown to affect sediment erosion and transport (Dunne et al., 1998), the composition of the particulate matter (Devol et al., 1995), carbon fluxes (Pettit et al., 2011), and nutrient supply (Villar et al., 1998).

The type of organic matter transported by tropical rivers covaries with discharge. Both the Tana River in Kenya (Tamooh et al., 2014) and the Sanaga River in Cameroon (Bird et al., 1998) transported mainly organic matter from the degradation of $\mathrm{C}_{4}$ plants during the wet season, while dry-season runoff is characterized by organic matter originating from $\mathrm{C}_{3}$ plants. Spencer et al. (2010) also showed that the properties of organic carbon transported by a tributary of the Congo River vary during different hydrographic phases, with highest dissolved organic carbon and lignin concentrations during peak flow. In the same river, the particulate organic carbon concentration increased when the discharge increased (Mariotti et al., 1991).

Following the construction of dams, the hydrological and sediment-related changes have been assessed in several systems, including the Tana River in Kenya (Maingi and Marsh, 2002) and the Lower Mekong River in China (Kummu and Varis, 2007; Fu et al., 2008; Lu and Siew, 2006). However, the impacts of these changes in hydrography on the biogeochemistry of tropical floodplain systems have hardly been studied. Considering the importance of floodplains within the catchment of large tropical rivers, changes in flooding and inundation might have pronounced effects on the biogeochemical behavior of floodplains and can have far-reaching consequences for the downstream catchment.

In this study, we assessed the dynamics and export rates of organic matter and nutrients in two large, understudied floodplains in the Zambezi River basin - the pristine Barotse Plains and the dam-impacted Kafue Flats - during wet- and dry-season conditions. This comparative analysis aims at identifying effects of damming on floodplain biogeochemistry and builds on previous studies on river-floodplain interactions in the Kafue Flats (Zurbrügg et al., 2012, 2013; Wamulume et al., 2011). Based on field campaigns from contrasting seasons, we were able to describe seasonal variability in the two systems. We further quantified the changes in the concentration, speciation, origin, and loads of carbon, nitrogen, and phosphorus along the floodplains in order to assess the implications of river damming and an altered hydrological regime on floodplain biogeochemistry.

\section{Study sites}

At $1.4 \times 10^{6} \mathrm{~km}^{2}$, the Zambezi River basin is the fourth largest in Africa, and the only major African river draining into the Indian Ocean. Due to its geographic location, the catchment experiences a pronounced wet season during the passage of the Intertropical Convergence Zone (DecemberMarch) and a dry season (April-November) during the remainder of the year.

The Barotse Plains are a near-pristine floodplain area in the upstream part of the Zambezi River in the western part of Zambia (Fig. 1). The hydrography in the Barotse Plains clearly reflects the climatic conditions, with peak flow around April or May and low flow between July and November (Fig. 2a). The total inundatable area is estimated at around $7700 \mathrm{~km}^{2}$. (Hughes and Hughes, 1992). The Kafue Flats are located along the Kafue River, one of the largest tributaries of the Zambezi River. Upstream of the Flats, the Itezhi-Tezhi dam (ITT, completed in 1978) stores a significant part of the wet-season runoff in order to allow for a 


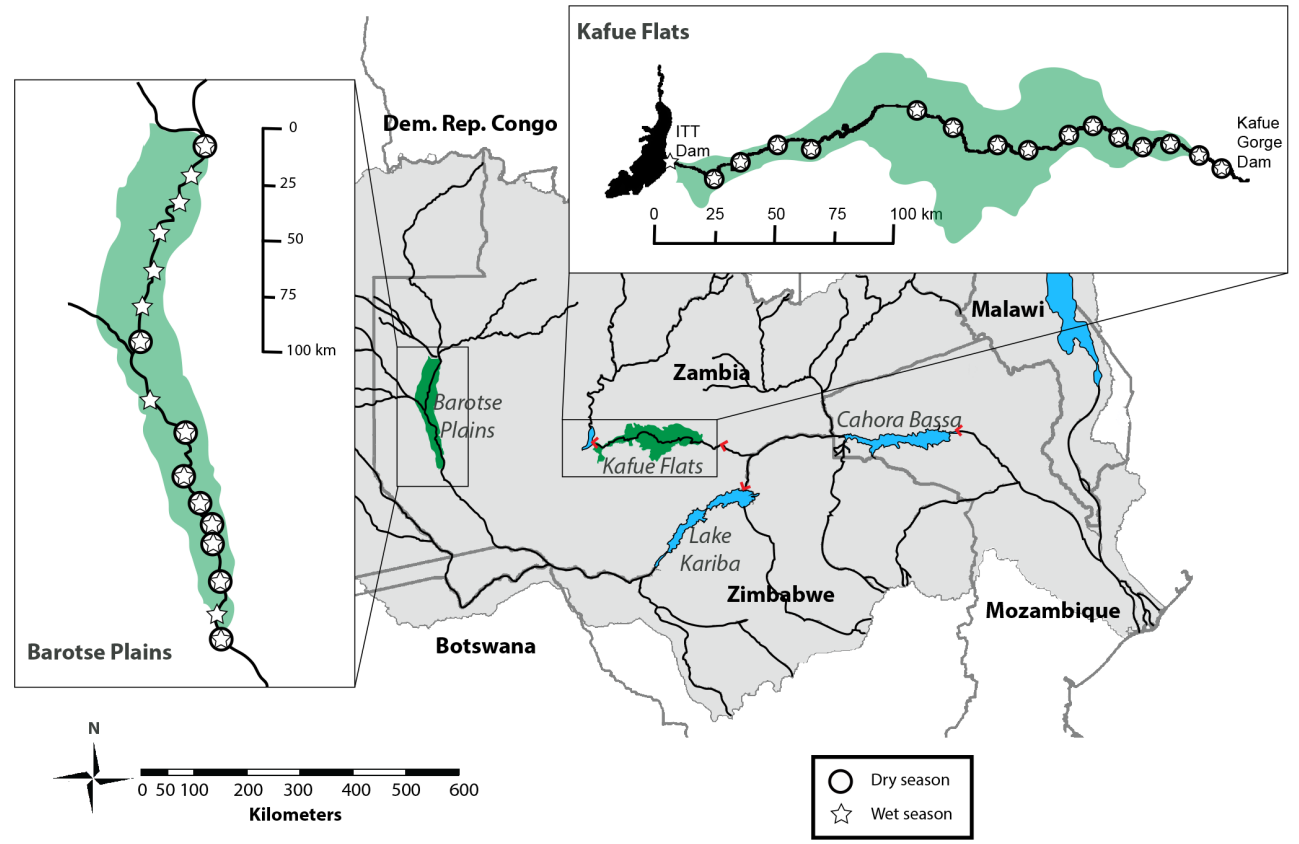

Figure 1. Map of the Zambezi catchment, with floodplains (in green) and large dams (red arrows) marked. Inserts show sampling stations during the dry (circles) and wet season (stars) in the Barotse Plains and Kafue Flats. Sampling stations will be further presented in distance along the river $(\mathrm{km})$.

continuous operation of the power station at Kafue Gorge (dam completed in 1972) downstream of the Kafue Flats. Evaporation from the reservoir changes the water level by $780 \mathrm{~mm}_{\text {year }}{ }^{-1}$, according to Beilfuss (2012). At $6000 \mathrm{~km}^{2}$, the maximum inundated area of the Kafue Flats is smaller than that of the Barotse Plains (Hughes and Hughes, 1992). The hydrography of the Kafue Flats has been significantly altered by the presence of the dams (Fig. 2b), but the annual discharge did not change. Over the last decades, peak flow has been reduced (approximately $-50 \%$ ) and base flow has increased (roughly $+50 \%$, Fig. $2 \mathrm{~b}$ ). In consequence, timing and extent of inundation in the Kafue Flats have changed (Mumba and Thompson, 2005). The floodplain area has been reduced by $40 \%$ due to permanent inundation, a direct result of elevated base flow sustained by the dam operation.

The vegetation in the Kafue Flats has been described as a gradient, ranging from open water to floodplain grasslands, water meadows, littoral zones, termitaria grasslands, and woodland areas (Ellenbroek, 1987). After the construction of the dams, the area covered by shrubs has increased (Mumba and Thompson, 2005; Blaser, 2013). For the Barotse Plains a detailed overview of the vegetation zones is lacking, but several sources suggest grasslands, combined with Miombo woodland and deciduous forest patches (Zambezi Society, 2000; Timberlake, 2000).

\section{Methods}

\subsection{Sampling}

Sampling of the main river channel at multiple locations along the floodplains (Fig. 1) was conducted during peak flow, hereafter called the wet season (April or May; Barotse Plains 2009, 2013; Kafue Flats 2008, 2009, 2010), and low flow, referred to as the dry season (October; Barotse Plains 2008, 2013; Kafue Flats 2008). Samples were collected from surface water in the middle of the well-mixed channel $(50 \mathrm{~cm}$, Barotse Plains) or at mid-depth (Kafue Flats) using a peristaltic pump. The similarity of the results from different years (Zurbrügg et al., 2012, 2013) allowed the combination and averaging of the data sets in order to obtain generalized patterns for the two systems and seasons. Discharge in the main channel was measured using a RiverRay ADCP (acoustic Doppler current profiler; for the Barotse Plains, dry-season data from the Zambezi River Authority were used).

\subsection{Laboratory analyses}

Samples for dissolved nutrient concentrations were filtered through $0.45 \mu \mathrm{m}$ filters. Dissolved inorganic nitrogen (DIN, limit of quantification, LOQ, of nitrogen analyses $<4 \mu \mathrm{M}$ ), phosphate (LOQ phosphorus analyses $<0.2 \mu \mathrm{M}$ ), and the sum of nitrate and nitrite were measured by chemiluminescence detection (Antek 9000). Ammonium was determined 
by standard colorimetric technique. Total dissolved nitrogen and total phosphorus (TDN and TDP) were determined by chemiluminescence detection (Antek 9000) following persulfate oxidation (Solórzano and Sharp, 1980; Bronk et al., 2000). Samples for particulate phosphorus concentrations during the wet season were collected onto $0.7 \mu \mathrm{m} \mathrm{GF} / \mathrm{F}$ filters (Whatman) and measured using a sequential phosphorus extraction method (SEDEX, Ruttenberg (1992), as modified by Slomp et al., 1996). Samples for dissolved organic carbon (DOC, precision $<10 \mu \mathrm{M}$ ) and dissolved inorganic carbon (DIC, precision $<10 \mu \mathrm{M}$ ) were filtered through $0.7 \mu \mathrm{m} \mathrm{GF} / \mathrm{F}$ filters (Whatman) and analyzed on a Shimadzu TOC-L (Barotse Plains) and on a Shimadzu 5050 TOC analyzer (Kafue Flats, DOC only). DIC concentrations for the Kafue Flats were calculated from $\mathrm{pH}$ and alkalinity measurements (data not shown). Stable oxygen isotopes were determined on filtered water samples $(0.45 \mu \mathrm{m}$ nylon filters) using a Picaro L2120-I Cavity Ringdown Spectrometer (Barotse Plains, precision $0.05 \%$ ) or a MultiFlow preparation module connected to a continuous-flow IRMS (isotope ratio mass spectrometer; Isoprime, UK, precision $0.2 \%$; Kafue Flats) and calibrated against in-house standards ranging from 0 to $-22.5 \%$ ovsMow. Riverine suspended matter was collected on pre-weighed GF/F filters (Whatman). After freeze-drying of samples, suspended matter concentrations were determined by weight difference. Particulate organic carbon and nitrogen and their stable isotopic compositions (POC, PN, $\delta^{13} \mathrm{C}$, and $\delta^{15} \mathrm{~N}$, respectively) were determined using an elemental analyzer-isotope ratio mass spectrometer (EA-IRMS; Thermo-Fischer MAT 253 or ThermoFinnigan FlashEA 1112 coupled to a DeltaV Advantage Continuous-Flow IRMS) and calibrated against in-house standards ( $\delta^{13} \mathrm{C}:-15$ to $-30 \%$ oVPDB, precision $0.1 \%$; $\delta^{15} \mathrm{~N}$ : -1.1 to $+32.7 \%$ air, precision $0.2 \%$ o) .

\section{Results}

\subsection{Hydrology and oxygen isotopes}

During the wet season, the runoff in the main channel of both floodplains was characterized by a discharge minimum roughly in the middle of both systems (Fig. 3). Located around $100 \mathrm{~km}$ and $200-300 \mathrm{~km}$ downstream in the Barotse Plains and in the Kafue Flats, respectively, constrictions in the riverbed were present, which promoted flooding of the surrounding floodplain area (Zurbrügg et al., 2012). During the dry season, the discharge remained fairly constant in both systems with a gain due to tributaries along the Barotse Plain and a slight loss in the Kafue Flats. Note, however, that the peak discharge in the wet season was about 4 times higher in the Zambezi crossing the Barotse Plains compared to the dammed Kafue River (Fig. 2).

The intense river-floodplain exchange left a distinct $\delta^{18} \mathrm{O}$ signal in both systems: the rivers lost water to the floodplain

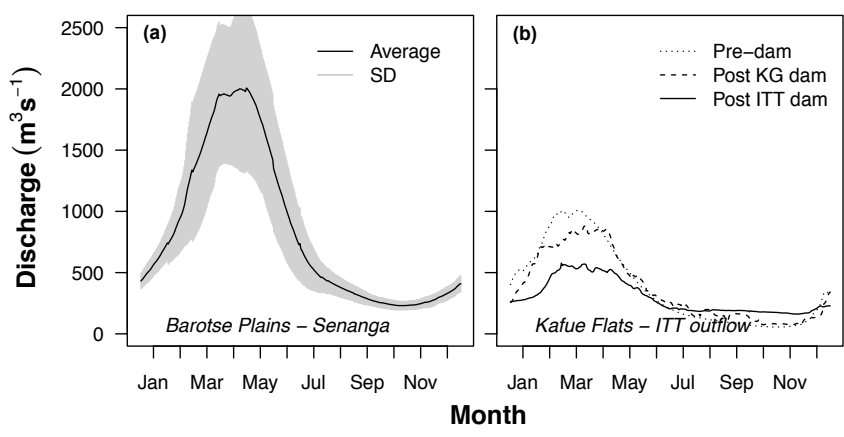

Figure 2. River discharge (a) at Senanga, the downstream boundary of the Barotse Plains (1988-2006 average and standard deviation), and (b) at the outflow of Itezhi-Tezhi (ITT) dam, the upstream boundary of the Kafue Flats. Discharge for the Kafue Flats are means of pre-dam (1960-1971) and post-dam construction (Kafue Gorge dam: 1972-1977; ITT dam: 1978-2010) periods. Data from the Department of Water Affairs and Zambezi River Authority; permission for reprint first granted to Blaser (2013).

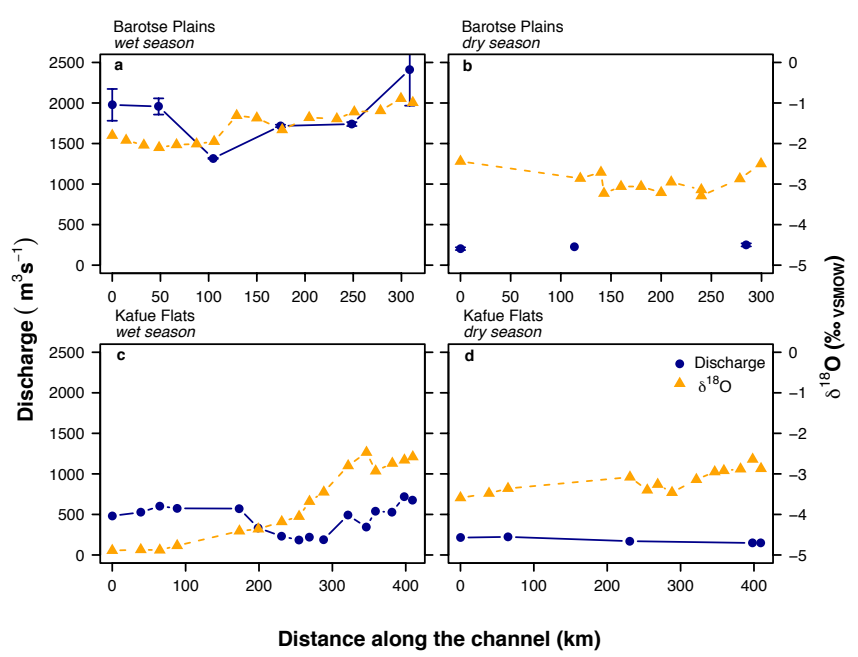

Figure 3. Discharge and stable oxygen isotope signals in the Barotse Plains and the Kafue Flats during wet and dry seasons. Discharge and $\delta^{18} \mathrm{O}$ data for the Kafue Flats have been published previously in Zurbrügg et al. (2012).

during the wet season. Downstream of the stretch where discharge in the river decreased, the $\delta^{18} \mathrm{O}$ of the river water changed sharply to heavier values (Fig. 3). The overall ${ }^{18} \mathrm{O}$ enrichment of the channel water between the upstream and downstream sampling locations was more pronounced in the Kafue Flats during the wet season. In the Barotse Plains, the $\delta^{18} \mathrm{O}$ signal showed an overall shift from $-2.0 \%$ in the upstream part to $-0.9 \%$ at the downstream end. In the Kafue Flats a sharp increase towards heavier values was observed downstream of the channel constriction. To correct for different travel distances along the river stretches, the change in $\delta^{18} \mathrm{O}$ per $100 \mathrm{~km}$ of river length was estimated: for the Barotse Plains this enrichment was $+0.26 \%$ and for the Ka- 
fue $+0.56 \%$ op $100 \mathrm{~km}$. During the dry season, no significant increase in the isotopic signal of oxygen was observed in the Barotse Plains, while in the Kafue Flats enrichment occurred at $+0.17 \%$ o per $100 \mathrm{~km}$.

\subsection{Concentrations and loads}

For a comprehensive comparison of the concentrations of carbon, nitrogen, and phosphorus species along the two floodplains during contrasting seasons, all measurements along the floodplain have been considered, irrespective of spatial trends (Fig. 4). The occurrence of large spatial variations along the floodplain, or differences between measurement methods between the different years, resulted in larger ranges.

The dissolved inorganic fraction dominated the total carbon concentration in both seasons and both systems (Fig. 4). Dissolved organic nitrogen (DON) was always the main nitrogen species. In the Barotse Plains particulate phosphorus (PP) was the dominant form during the wet season, while dissolved inorganic phosphorus (DIP) was generally the prevailing species during the dry season. Phosphorus concentrations were largely close to the detection limit in both systems, and were therefore excluded from the calculation of loads.

While both systems exhibited very low inorganic nutrient concentrations during the dry season, the Barotse Plains were substantially lower in organic carbon and nitrogen species concentration compared to the Kafue Flats. Differences between the dry-season and wet-season $\mathrm{C}$ and $\mathrm{N}$ concentrations within both systems were statistically significant (paired analysis, $p$ values $<0.05$ ) for all species, except for the Kafue Flats DOC ( $p=0.23)$, DON (0.084), and DIN (0.284). The differences in concentrations between the Barotse Plains and Kafue Flats in similar seasons were significant (hypothesis testing, $p$ values $<0.05$ ) for all species except PP (wet season, $p=0.121$ ) and DIP (dry season, $p=0.053$ ).

Loads were calculated from the discharge and concentration data for the respective species, as the water column was well mixed (see Supplement). Total carbon and nitrogen loads increased along the Barotse Plains during the wet season, mainly due to a larger contribution from the dissolved organic form (Fig. 5). The increase in total carbon load in the Kafue Flats during the wet season was mainly attributed to the dissolved inorganic fraction. The magnitude of the wetseason carbon loads leaving the floodplain area was comparable between the two systems (roughly $1500 \mathrm{t} \mathrm{C} \mathrm{d}^{-1}$, Fig. 5), while the nitrogen loads in the Barotse Plains were almost twice as high as those in the Kafue Flats (44 and $20 \mathrm{t} \mathrm{N} \mathrm{d}^{-1}$ ). During the dry season the loads decreased slightly.

Net export was determined as the difference between the load at the downstream end of the floodplain and the load at the upstream end of the floodplain (Table 1). During the wet season, the Barotse Plains were a sink for all particulate phases, while the Kafue Flats acted as a source (Table 1). Both systems were sources of DOC and DIC. Dissolved or- ganic nitrogen was exported from both floodplains, but the Barotse Plains retained the small DIN flux, while the Kafue Flats were a minor source. During the dry season, the Barotse Plains acted as source of particulate matter. For the Kafue Flats this could not be determined due to a lack of POC and $\mathrm{PN}$ measurements in the downstream stretches of the river. DOC and DIC were retained by both systems. The Barotse Plains were a minor source of dissolved nitrogen, while the Kafue Flats retained both organic and inorganic nitrogen.

\section{3 $\mathrm{C}: \mathrm{N}$ ratios and isotopes}

The $\mathrm{C}: \mathrm{N}$ ratios of particulate organic matter (Fig. 6) remained fairly constant along the floodplain in the Barotse Plains and Kafue Flats during the wet season $(10.8 \pm 0.7$ and $7.5 \pm 0.7$, respectively (statistically significant difference at $95 \%$ confidence intervals)). During the dry season the along-floodplain variability within each of the floodplains was larger (10.3 \pm 1.5 and $10.3 \pm 1.8$, respectively), but no significant difference was observed between the two systems. On average, particulate carbon was more depleted in ${ }^{13} \mathrm{C}$ in the Kafue Flats than in the Barotse Plains during the wet season $\left(\delta^{13} \mathrm{C}=-28.5 \pm 0.9\right.$ and $-26.9 \pm 1.1 \%$, respectively (statistically significant $p<0.05$ )). During the dryseason, mean $\delta^{13} \mathrm{C}$ values were $-28.5 \pm 1.0 \%$ in the Barotse Plains and $-26.5 \pm 1.9 \%$ in the Kafue Flats, again a significant difference. The organic matter in the Barotse Plains became more enriched in ${ }^{13} \mathrm{C}$ during the wet season compared to the dry season, while in the Kafue Flats lower $\delta^{13} \mathrm{C}$ values were observed during the wet season than during the dry season (both significant, $p<0.05$ ).

The $\mathrm{C}: \mathrm{N}$ ratio of the dissolved organic phase was more variable: while the wet-season values of $17.5 \pm 1.9$ and $23.7 \pm 3.4$ were fairly similar for the Barotse Plains and Kafue Flats, respectively, they differed widely during the dry season: $166 \pm 20$ and $22.7 \pm 11.3$. The two systems differed significantly $(p<0.05)$ from each other during a given season.

Paired analysis showed that there was no statistically significant $(p<0.05)$ difference in particulate $\mathrm{C}: \mathrm{N}$ ratios in the Barotse Plains between contrasting seasons, while there was a difference in dissolved $\mathrm{C}: \mathrm{N}$ ratios and $\mathrm{C}$-isotopic signals. In the Kafue Flats, there was a significant decrease in particulate $\mathrm{C}: \mathrm{N}$ ratio from the dry to the wet season (as previously reported in Zurbrügg et al., 2013).

\section{Discussion}

\subsection{Hydrology and inundation dynamics}

The discharge patterns (Fig. 3) showed how the bankfull capacity of the Zambezi and Kafue rivers varied along the floodplain stretch. In both systems water moved from the main channel onto the floodplain, at roughly 600 and $400 \mathrm{~m}^{3} \mathrm{~s}^{-1}$ in the Barotse Plains and the Kafue Flats, re- 

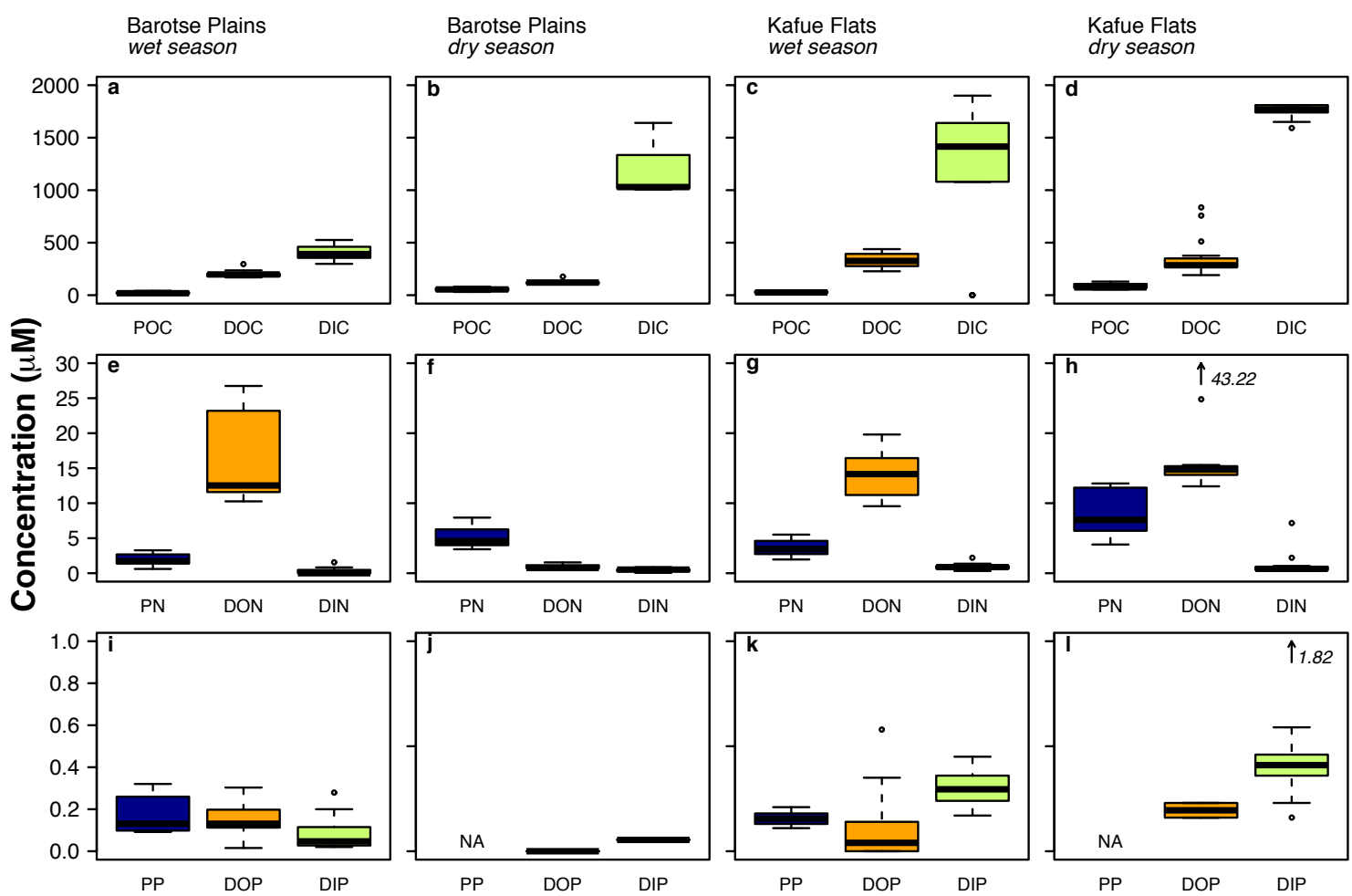

Figure 4. Boxplots of the concentrations of dissolved and particulate carbon, nitrogen, and phosphorus species along the Barotse Plains and the Kafue Flats during wet and dry seasons along the floodplain. The boxes represent the first and third quartiles, and the median. No measurements of particulate phosphorus were made on samples from the dry seasons. Carbon and nitrogen data of the Kafue Flats have been previously published in Zurbrügg et al. (2013).

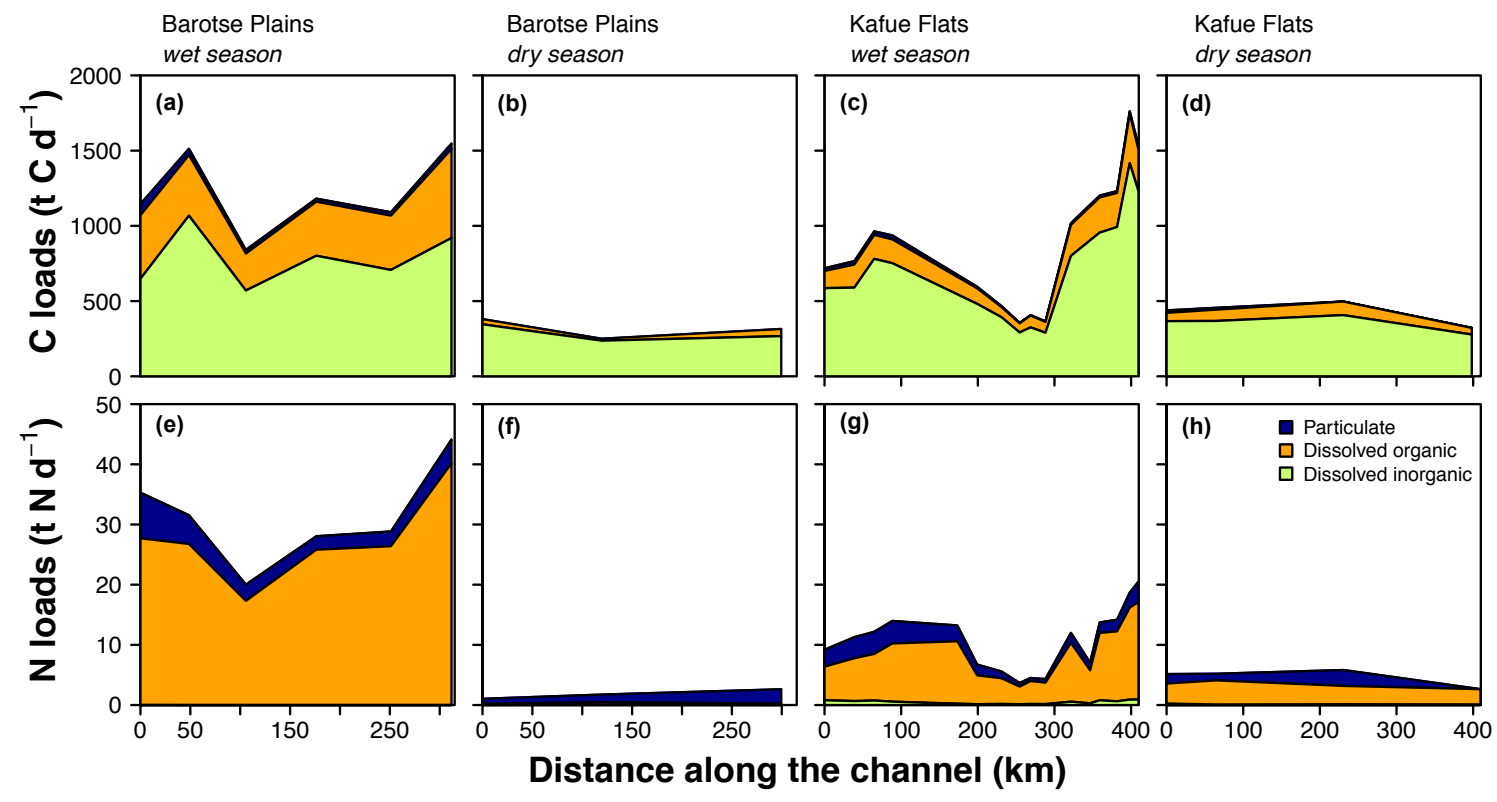

Figure 5. Dissolved and particulate carbon and nitrogen loads along the Barotse Plains and the Kafue Flats during wet and dry seasons. The loads of particulate carbon and nitrogen at the two most downstream locations in the Kafue Flats could not be determined for the dry season due to a lack of POC and PN measurements. 
Table 1. Net export (in tons of $\mathrm{C}$ per day and tons of $\mathrm{N}$ per day), calculated as the difference between loads at the downstream and upstream ends of the respective floodplain, from the two floodplains during wet and dry seasons. Positive numbers indicate that the floodplain acted as a source (export), negative numbers indicate the floodplain acting as a sink (retention). POC and PN export from the Kafue Flats during the dry season could not be estimated due to a lack of measurements at downstream locations.

\begin{tabular}{lcrrrrrr}
\hline \multicolumn{2}{c}{ System } & POC & DOC & DIC & PN & DON & DIN \\
\hline \multirow{2}{*}{ Barotse Plains } & Wet season & -38 & 170 & 270 & -3.7 & 12 & 0.0 \\
& Dry season & 14 & -1.5 & -78 & 1.6 & 0.0 & 0.0 \\
\multirow{3}{*}{ Kafue Flats } & Wet season & 6.5 & 160 & 640 & 0.6 & 11 & 0.1 \\
& Dry season & NA & -11 & -89 & NA & -0.8 & -0.2 \\
\hline
\end{tabular}

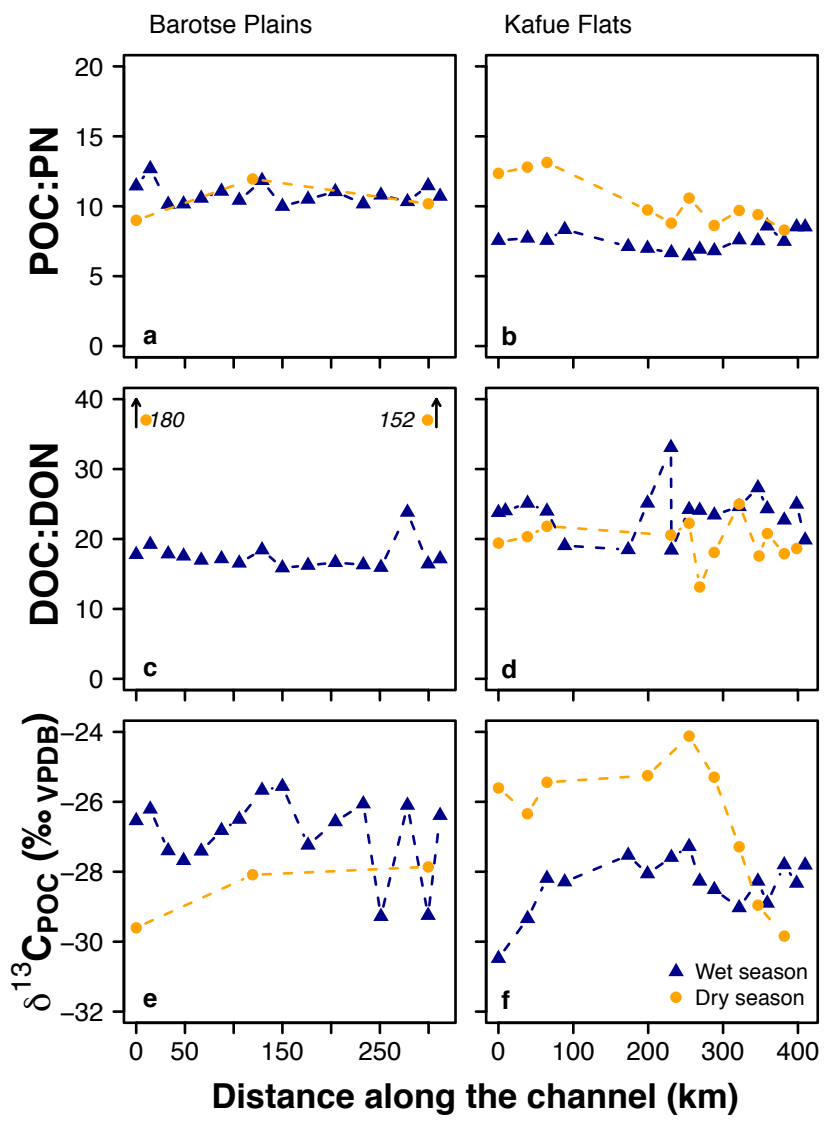

Figure 6. Carbon to nitrogen $(\mathrm{C}: \mathrm{N})$ ratios of particulate and dissolved organic matter as well as carbon isotopic signatures of particulate organic matter during wet (blue triangles) and dry (orange circles) seasons. The Kafue Flats data have been previously published in Zurbrügg et al. (2013).

spectively. Where the capacity of the channel increases again further downstream, water from the floodplains (and potential tributaries) returned to the main channel at higher rates. On the floodplain, flow velocities were extremely low $\left(<1 \mathrm{~mm} \mathrm{~s}^{-1}\right.$ on the Kafue Flats in May 2008; unpublished data), which led to prolonged residence times of the water on the floodplain, during which evaporation might occur, resulting in heavier $\delta^{18} \mathrm{O}$ signatures in floodplain water.
Using a mass balance approach based on oxygen isotopic data, Zurbrügg et al. (2012) calculated that $>80 \%$ of the water in the Kafue Flats was on the floodplain for a certain amount of time during the wet season. Logistical constraints prevented the collection of similar remote floodplain samples in the Barotse Plains. Assuming a similar floodplain signal in the Barotse Plains as in the Kafue Flats, a first approximation was made to determine how much water in the Barotse Plains had been on the floodplain. This resulted in $50 \%$ of the water leaving the pristine floodplain area also having been outside the channel for a certain amount of time. This estimate shows that the interaction between river and floodplain was stronger in the Kafue Flats than in the Barotse Plains and reinforces the observation that a larger fraction of the river discharge in the Kafue Flats was forced onto the floodplain at the constriction location than in the Barotse Plains. In the published literature, high contributions of floodplain-derived water are also reported for the Tonle Sap Lake-floodplain system, where water from the Mekong contributed over $50 \%$ to the inflows of the lake and more than $80 \%$ of the outflows from the lake returned to the main river channel of the Mekong (Kummu et al., 2014). At peak flow in the Amazon, $97 \%$ of the river inflow occurred at overbank flow at the Curuai floodplain, and this water was on the floodplain for an average of 19 days, according to the modeling results by Rudorff et al. (2014).

During the dry season, the increasing discharge along the Barotse Plains is most likely caused by inflow of the Luanginga tributary. By contrast, the decreasing discharge in the Kafue Flats combined with a calculated $16 \%$ of the downstream discharge that had been on the floodplain for a certain amount of time (Zurbrügg et al., 2012) indicated that there was still exchange between the river channel and some permanently inundated areas in the downstream reaches of the Kafue Flats. From a regional perspective, the along-floodplain increase in the $\delta^{18} \mathrm{O}$ signal in the Barotse Plains and Kafue Flats during the wet (flooding) season $(+0.21 \%$ ovsMOv to $+0.56 \%$ ovsMOv per $100 \mathrm{~km})$ was considerably lower than the increase in the Okavango Delta during the dry (flooding) season $(+2.04 \%$ opr $100 \mathrm{~km})$ and during wet season $(+0.74 \%$ ovSMOv per $100 \mathrm{~km}$; calculated from Akoko et al., 2013), indicating that there was significantly 
less extensive evaporation on the Zambezi catchment floodplains than in the inland Okavango delta.

\subsection{Seasonality of $\mathrm{C}$ and $\mathrm{N}$ export and retention}

During the wet season, the Barotse Plains were characterized by a net export of dissolved phases and retention of particulate material. Degradation processes or settling of particulate organic matter, either in the main channel or on the floodplain, could result in apparent retention of POC and PN. The concurrent export of DOC, DIC, and DON could similarly be a result of degradation or of the leaching of vegetation or soils. During the dry season, the patterns were reversed, indicative of inputs of organic matter from the Barotse Plains.

In contrast, the Kafue Flats were a net source for both particulate and dissolved phases during the wet season, indicating a different balance. The high proportion of DIC to the net dissolved $\mathrm{C}$ export suggests that degradation was a dominant process during flooding. While the constant POC: PN ratios contradict large soil inputs, a combination of primary production around the edges of the main channel, and degradation and leaching of soil and vegetation from the inundated floodplain (indicated by low oxygen concentrations in the water from the floodplain; Zurbrügg et al., 2012), could be responsible for the observed patterns. During the dry season, the retention of DOC, DIC, DON, and DIN pointed towards primary production and potentially a minor contribution from sorption of dissolved organic phases onto particulate material.

The observed net export of particulate organic matter may not have effects beyond the downstream reservoirs of Lake Kariba and Kafue Gorge (Fig. 1). Both impoundments will trap mobilized particles, and 70 and $90 \%$ of incoming total $\mathrm{N}$ and $\mathrm{P}$ are retained within Lake Kariba (Kunz et al., 2011a). Over the course of a year, the Barotse Plains were a sink for particulate phases, while both the Barotse Plains and the Kafue Flats were exporting large quantities of dissolved organic matter (Table 2). The export of dissolved organic matter, especially DOC, was 2-4 times higher than yields previously reported for the Zambezi catchment (Mayorga et al., 2010). The numbers are closer in magnitude to yields reported for the Amazon and Orinoco rivers, which both drain highly productive tropical rainforest (Beusen et al., 2005; Harrison et al., 2005; Lewis Jr. and Saunders III, 1989). Since the Zambezi mainly drains savanna ecosystems, catchment yields are a lot lower than from the other tropical rivers (Table 2). The negative yields of particulate matter show how floodplains can impact the riverine loads in trends opposite to those observed for the whole catchment. Additionally, the high dissolved organic matter yields further indicate that floodplains are intense biogeochemical reactors, which significantly affect riverine transport of organic matter from land to sea.

\subsection{Sources of organic matter}

\subsubsection{Dissolved organic matter}

Based on the export and retention behavior of the two floodplains, degradation of floodplain-derived organic matter may be a large source of DOC in the Barotse Plains during the wet season. During the dry season, primary production, organic matter inputs from the floodplain, and sorption of dissolved organic phases to particles may have decreased the DOC concentrations. In the Kafue Flats, degradation of organic matter on the floodplain contributed to in-stream DOC during the wet season, whereas during the dry season, similarly to the Barotse Plains, primary production and sorption of dissolved phases onto particles were lowering DOC and DON concentrations. The high contribution of DON to TDN further indicates that the Zambezi and Kafue Rivers are still in large parts pristine, as anthropogenic activities mainly add nitrogen in the form of DIN to aquatic systems (Berman and Bronk, 2003).

The elevated $\mathrm{C}: \mathrm{N}$ ratio of the dissolved organic matter was indicative of the terrestrial origin of the organic material in both systems. The ITT reservoir did not have a pronounced impact on the dissolved phase $(\mathrm{C}: \mathrm{N}$ around 23 during both seasons), which has previously been attributed to a mostly refractory dissolved organic-matter phase (Zurbrügg et al., 2013). The comparison with the Barotse Plains revealed a much larger variability in $\mathrm{C}: \mathrm{N}$ of the dissolved matter, reaching dry-season values of 166 compared to the wet-season signatures around 18 . While DOC concentrations were fairly similar during both seasons, the large decrease in DON concentrations from the wet to the dry season (Fig. 4) has resulted in this shift in dissolved $\mathrm{C}: \mathrm{N}$ ratio.

The growth of seasonal vegetation on the inundated floodplain resulted in a large leaching potential of dissolved organic substances during the wet season, showing how processes on the floodplain affect the riverine biogeochemistry in this biogeochemical reactor. The increase in DOC and DON concentrations during the wet season in the Barotse Plains compared to the dry season also corresponds to the general observation that DOC export increases with runoff, caused by the shallowing of the flow paths through organicrich upper soils (Mulholland, 2003; Aitkenhead-Peterson et al., 2003). Seasonal variability in DOC and DON concentrations has been previously shown in Hawaii (Wiegner et al., 2009) and Congo (Spencer et al., 2010). In Hawaii, flow paths are thought to change during changing hydrological conditions, and in Congo seasonal changes were considered indicative of different sources of dissolved organic matter, flow paths, and residence times. Runoff from inundated soils, such as found in the Zambezi River basin during the wet season, also tend to have higher DON concentrations (Aitkenhead-Peterson et al., 2003). This (potentially refractory) source of DON might be responsible for the high DON concentrations found in the Barotse Plains during the wet 
Table 2. Yields of carbon, nitrogen, and phosphorus in kilograms ( $\mathrm{C}$ or $\mathrm{N})$ per square kilometer per year from large river basins and floodplain yields from the Barotse Plains and Kafue Flats. Yields for this study are calculated from the maximum inundated areas mentioned in the "Study Sites" section, assuming 6 months of dry-season export and 6 months of wet-season export. POC and PN yields from the Kafue Flats during the dry season could not be estimated due to a lack of measurements at downstream locations, so no yearly yields were calculated.

\begin{tabular}{lrrrrr}
\hline River & POC & DOC & PN & DON & DIN \\
\hline Amazon & $2900^{\mathrm{a}}$ & $5200^{\mathrm{d}}$ & $500^{\mathrm{a}}$ & $330^{\mathrm{d}}, 180^{\mathrm{f}}$ & $170^{\mathrm{f}}$ \\
Congo & $1400^{\mathrm{a}}, 400^{\mathrm{c}}$ & $3300^{\mathrm{a}}, 1600^{\mathrm{c}}$ & $200^{\mathrm{a}}$ & $92^{\mathrm{c}}, 58^{\mathrm{f}}$ & $32^{\mathrm{f}}$ \\
Orinoco & $1500^{\mathrm{e}}$ & $5600^{\mathrm{d}}, 5200^{\mathrm{e}}$ & $190^{\mathrm{e}}$ & $310^{\mathrm{d}}, 190^{\mathrm{e}}, 170^{\mathrm{f}}$ & \\
Oubangui & $180-300^{\mathrm{b}}$ & $660-1500^{\mathrm{b}}$ & $20-29^{\mathrm{b}}$ & & \\
Zambezi & $800^{\mathrm{a}}$ & $1000-2000^{\mathrm{f}}$ & $100^{\mathrm{a}}$ & - & $14^{\mathrm{f}}, 100-300^{\mathrm{g}}$ \\
\hline This study: & & & & & \\
Barotse Plains & -570 & 4000 & -50 & 300 & -0.1 \\
Kafue Flats & NA & 4600 & NA & 300 & -1.5 \\
\hline
\end{tabular}

Sources: ${ }^{a}$ Beusen et al. (2005), ${ }^{\mathrm{b}}$ Bouillon et al. (2014), ${ }^{\mathrm{c}}$ Esser and Kohlmaier (1991), ${ }^{\mathrm{d}}$ Harrison et al. (2005), ${ }^{\mathrm{e}}$ Lewis Jr. and Saunders III (1989), ${ }^{\mathrm{f}}$ Mayorga et al. (2010), ${ }^{\mathrm{g}}$ Hall et al. (1977).

season. For the Kafue Flats, there was no significant seasonal change in DOC and DON concentrations between the wet and dry seasons. This might be due to the fact that an increase in DOC and DON concentration in the upstream catchment would be diluted and delayed by the presence of the ItezhiTezhi dam, showing after peak flow. With a residence time of 0.7 years, large fractions of organic carbon $( \pm 16 \%)$ and nutrient loads $(50 \% \mathrm{~N}, 60 \% \mathrm{P})$ were trapped in the sediments of the reservoir (Kunz et al., 2011b). Monthly measurements showed that the highest TOC concentrations occurred in the main channel in the floodplain area in May or June after the peak flow (Wamulume et al., 2011). This could be a delayed effect of the increased concentrations at higher runoff during the wet season (November-March).

\subsubsection{Particulate organic matter}

The higher $\mathrm{C}: \mathrm{N}$ ratio of the suspended matter in the Barotse Plains compared to the Kafue Flats indicates a year-round soil-derived source in the pristine part of the catchment. In contrast, $\mathrm{C}: \mathrm{N}$ ratios found in the Kafue Flats during the wet season were indicative of aquatic production (Zurbrügg et al., 2013). This could be attributed to the presence of the ITT reservoir: both sediment trap data (Kunz et al., 2011b) and surface sediments from the reservoir (Supplementary information of Zurbrügg et al., 2013) showed a $\mathrm{C}: \mathrm{N}$ ratio elevated from that observed in the Kafue Flats $(12.1 \pm 0.6)$, similar to the numbers found for the suspended matter in the Barotse Plains. While degradation in the reservoir might also affect the $\mathrm{C}: \mathrm{N}$ ratios, this typically leads to an increase. The observed difference between $\mathrm{C}: \mathrm{N}$ ratios in the reservoir and in the river is therefore attributed to different sources. The presence of the dam significantly affected the chemical composition of the suspended matter, and while soil-derived suspended matter settled in the reservoir, mainly photosynthetically produced organic matter from the reservoir surface waters reached the Kafue Flats and eventually the Kafue-
Zambezi confluence. The decrease in $\mathrm{C}: \mathrm{N}$ ratio along the floodplain in the Kafue Flats during the dry season could be indicative of gradual organic-matter input from nitrogenfixing vegetation. As a consequence of nutrient elimination in the ITT reservoir, widespread encroachment of N-fixing woody plants onto the floodplain has been observed (Blaser, 2013).

While the $\mathrm{C}: \mathrm{N}$ ratio showed little variation throughout the year in the Barotse Plains, the stable $\mathrm{C}$-isotopic signatures of the particulate matter further suggest different contributors to the POC in the river. During the wet season, the particulate organic matter in the Barotse Plains is ${ }^{13} \mathrm{C}$ enriched compared to the dry season $(-26.9$ and $-28.5 \%$, respectively). Organic-matter sources on the floodplain (soils on average $-18 \%$, abundant reeds between -12 and $-27 \%$; unpublished data) had distinctly heavier $\delta^{13} \mathrm{C}$ signatures than the permanent vegetation in the area (average of six different tree species $-28.3 \pm 1.22 \%$; unpublished data). Shifts to isotopically heavier organic matter during the wet season, as observed in the Barotse Plains, have been described for the Tana River in Kenya (Tamooh et al., 2014), the Sanaga River in Cameroon (Bird et al., 1998), and the Congo River in central Africa (Mariotti et al., 1991). For all these tropical rivers, the source of the organic matter transported by the river changed with inundation. Connectivity of floodplains during high-water conditions resulted in enriched stable isotopic values in the riverine organic matter. During the dry season, inputs from permanent terrestrial vegetation resulted in more depleted $\delta^{13} \mathrm{C}$ signatures.

In contrast, the particulate organic matter in the Kafue Flats was more enriched during the dry season compared to the wet season $(-26.5$ and $-28.5 \%$, respectively). The average dry-season $\delta^{13} \mathrm{C}$ value for the Kafue Flats should be interpreted with caution, since there was a clear spatial pattern: values became more depleted towards the edge of the floodplain. This spatial pattern has previously been attributed 

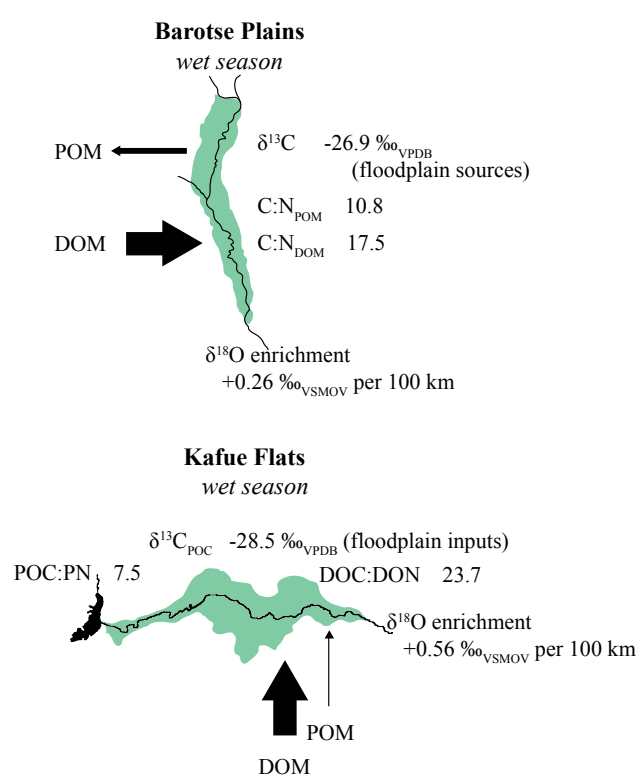
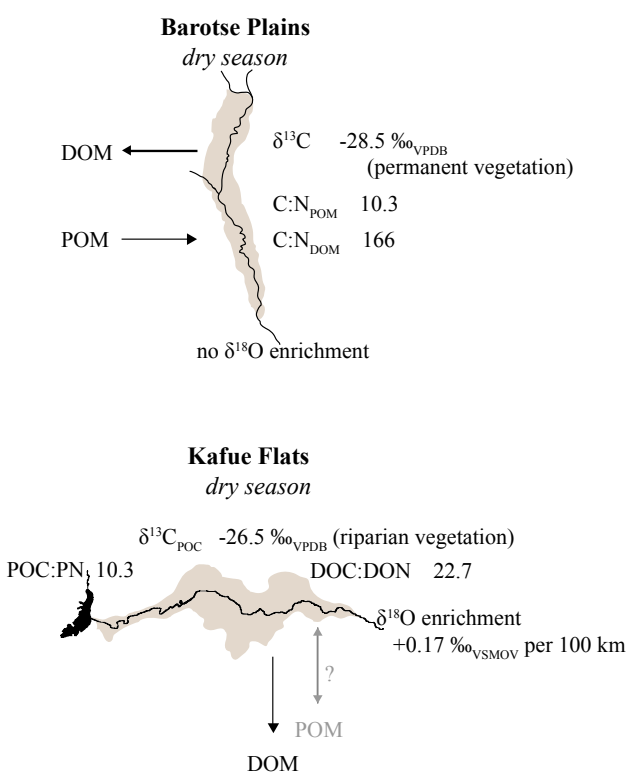

Figure 7. Summary of the organic-matter characteristics $\left(\delta^{13} \mathrm{C}, \mathrm{POC}: \mathrm{PN}, \mathrm{DOC}\right.$ : DON $)$ and oxygen isotopic enrichment along the floodplain during the wet and dry season in the Barotse Plains and Kafue Flats. Proportional arrows indicate net export from the floodplain to the river (arrow towards the system) and removal rates of material from the river to the floodplain (arrow away from the system) of POM (POC $+\mathrm{PN}$ ) and DOM (DOC+DON).

to floodplain-derived particulate organic matter, which would consist of phytoplankton and periphyton material in the permanently inundated area in the downstream reaches of this floodplain (Zurbrügg et al., 2013). In the upstream stretch of the floodplain that had more typical dry-season characteristics (i.e., no flooded areas), the dry-season value was heavier than the average reported earlier. Encroaching plant species have resulted in a vegetation pattern with $\mathrm{C}_{4}$ species occurring close to the river and $\mathrm{C}_{3}$ species growing on the higher ground that is only seasonally flooded (Blaser, 2013; Ellenbroek, 1987). The inputs from these encroaching species can be considered to be terrestrial inputs of permanent vegetation but as such resulted in a pattern contrasting with that observed in the Barotse Plains.

The difference in composition and origin between dissolved and particulate phases, i.e., DOM (dissolved organic matter) from terrestrial sources and POM (particulate organic matter) more aquatically influenced, has previously been described for the Amazon (Aufdenkampe et al., 2007; Hedges et al., 1986) and the Fly-Strickland system in Papua New Guinea (Alin et al., 2008). We showed that the interaction of the river with its floodplain is responsible for the changes observed in organic-matter characteristics and that floodplains should be considered as large biogeochemical reactors, which create specific environments that can differ from the processes occurring at the catchment level.

\section{Conclusions}

While the pristine Barotse Plains and dam-impacted Kafue Flats seem to have similar properties in terms of timing and dynamics of seasonal flooding, there are several marked differences between the two systems with respect to hydrology, carbon and nutrient dynamics, and the sources of the organic matter (Fig. 7). Based on an oxygen isotope mass balance, a larger fraction of water has spent time on the floodplain at the outflow of the Kafue Flats compared to the Barotse Plains. The two floodplains have significantly different concentrations of dissolved carbon and nutrient species during both wet and dry seasons. Over an annual cycle, the Barotse Plains retained particulate organic matter, and both floodplains exported more dissolved organic matter than previously reported for the Zambezi. This illustrates how large floodplain systems act as large biogeochemical reactors that behave distinctly differently from the rest of the catchment. Particulate organic carbon $\delta^{13} \mathrm{C}$ values indicated a larger contribution of floodplain-derived organic matter in the Barotse Plains than in the Kafue Flats during the wet season and the reverse situation during the dry season. However, the Kafue Flats have a reversed vegetation pattern as a consequence of woody encroachment towards the river, which was first observed after dam closure. Currently, permanent $\mathrm{C}_{4}$ vegetation is found close to the river, whereas the seasonal growth has larger $\mathrm{C}_{3}$ inputs; this is responsible for the seemingly contrasting patterns in particulate organic carbon $\delta^{13} \mathrm{C}$ signatures. Both floodplains transported floodplain-derived ma- 
terial during the wet season and inputs from permanent vegetation during the dry season.

Differences between the two systems can be attributed to the presence of the Itezhi-Tezhi reservoir upstream of the Kafue Flats, which altered the inputs to the particulate organicmatter pool in the Kafue Flats. Besides the effect of woody encroachment on the stable carbon isotopic signature, seasonal inputs of aquatic primary production in the upstream reservoir lowered the reactivity and $\mathrm{POC}$ : $\mathrm{PN}$ ratio in the $\mathrm{Ka}$ fue Flats during the wet season. By contrast, soil material was transported during the dry season and year-round in the Barotse Plains. In summary, river-damming-induced vegetation changes in the floodplain towards more woody plants and phytoplankton production added nitrogen-rich organic matter to the river system downstream.

\section{The Supplement related to this article is available online at doi:10.5194/bg-12-7535-2015-supplement.}

Author contributions. A. L. Zuijdgeest, R. Zurbrügg, D. B. Senn, and B. Wehrli were responsible for the study design. A. L. Zuijdgeest, R. Zurbrügg, N. Blank, and R. Fulcri performed the fieldwork and the laboratory analyses. Data analysis was performed by A. L. Zuijdgeest, R. Zurbrügg, and D. B. Senn and supported by N. Blank, R. Fulcri, and B. Wehrli. The manuscript was prepared by A. L. Zuijdgeest with contributions from all co-authors.

Acknowledgements. The authors thank Wilma Blaser, Griffin Shanungu, Cristian Teodoru, Jason Wamulume, Mongu harbor personnel, and the Zambia Wildlife Authority for fieldwork assistance. Laboratory analyses were supported by Stewart Bishop, Madalina Jaggi, and Daniel Montluçon (all ETH Zürich); Kate Ashe, Chantal Freymond, Patrick Kathriner, Gijs Nobbe, Ruth Stierli, Stephan Suter, and Prosper Zigah (all Eawag); and Moritz Lehmann and Mark Rollog (all University of Basel). Comments from Tim Kalvelage (ETH Zürich) and our two reviewers (Lex Bouwman and Tim Jennerjahn) improved the manuscript. Institutional support was provided by Imasiku Nyambe (University of Zambia and its Integrated Water Resource Management Center), the Zambia Wildlife Authority, the Zambezi River Authority, and the Zambia Electricity Supply Corporation. Funding for this study came from the Competence Center for Environment and Sustainability (CCES) of the ETH domain, the Swiss National Science Foundation (Grant No. 128707), and Eawag.

Edited by: S. Bouillon

\section{References}

Aitkenhead-Peterson, J. A., McDowell, W. H., and Neff, J. C.: 2 Sources, Production, and Regulation of Allochthonous Dissolved
Organic Matter Inputs to Surface Waters, in: Aquatic Ecosystems, edited by: Findlay, S. E. G. and Sinsabaugh, R. L., Academic Press, Burlington, 25-70, 2003.

Akoko, E., Atekwana, E., Cruse, A., Molwalefhe, L., and Masamba, W. L.: River-wetland interaction and carbon cycling in a semiarid riverine system: the Okavango Delta, Botswana, Biogeochemistry, 114, 359-380, doi:10.1007/s10533-012-9817-x, 2013.

Alin, S. R., Aalto, R., Goni, M. A., Richey, J. E., and Dietrich, W. E.: Biogeochemical characterization of carbon sources in the Strickland and Fly rivers, Papua New Guinea, J. Geophys. Res.Earth, 113, F01S05, doi:10.1029/2006jf000625, 2008.

Alvarez-Cobelas, M., Angeler, D. G., and Sánchez-Carrillo, S.: Export of nitrogen from catchments: A worldwide analysis, Environ. Pollut., 156, 261-269, doi:10.1016/j.envpol.2008.02.016, 2008.

Alvarez-Cobelas, M., Sánchez-Carrillo, S., Angeler, D. G., and Sánchez-Andrés, R.: Phosphorus export from catchments: a global view, J. N. Am. Benthol. Soc., 28, 805-820, doi:10.1899/09-073.1, 2009.

Alvarez-Cobelas, M., Angeler, D. G., Sánchez-Carrillo, S., and Almendros, G.: A worldwide view of organic carbon export from catchments, Biogeochemistry, 107, 275-293, doi:10.1007/s10533-010-9553-z, 2012.

Aufdenkampe, A. K., Mayorga, E., Hedges, J. I., Llerena, C., Quay, P. D., Gudeman, J., Krusche, A. V., and Richey, J. E.: Organic matter in the Peruvian headwaters of the Amazon: Compositional evolution from the Andes to the lowland Amazon mainstem, Org. Geochem., 38, 337-364, doi:10.1016/j.orggeochem.2006.06.003, 2007.

Barros, N., Cole, J. J., Tranvik, L. J., Prairie, Y. T., Bastviken, D., Huszar, V. L. M., del Giorgio, P., and Roland, F.: Carbon emission from hydroelectric reservoirs linked to reservoir age and latitude, Nat. Geosci., 4, 593-596, 2011.

Bastviken, D., Cole, J. J., Pace, M. L., and Van de Bogert, M. C.: Fates of methane from different lake habitats: Connecting wholelake budgets and $\mathrm{CH}_{4}$ emissions, J. Geophys. Res., 113, G02024, doi:10.1029/2007JG000608, 2008.

Beilfuss, R.: A Risky Climate for Southern African Hydro - Assessing hydrological risks and consequences for Zambezi River Basin dams, Technical Report, International Rivers, Berkeley, California, 2012.

Berman, T. and Bronk, D. A.: Dissolved organic nitrogen: a dynamic participant in aquatic ecosystems, Aquat. Microb. Ecol., 31, 279-305, 2003.

Beusen, A. H. W., Dekkers, A. L. M., Bouwman, A. F., Ludwig, W., and Harrison, J.: Estimation of global river transport of sediments and associated particulate $\mathrm{C}, \mathrm{N}$, and P, Global Biogeochem. Cy., 19, GB4S05, doi:10.1029/2005gb002453, 2005.

Bird, M. I., Giresse, P., and Ngos, S.: A seasonal cycle in the carbon-isotope composition of organic carbon in the Sanaga River, Cameroon, Limnol. Oceanogr., 43, 143-146, 1998.

Blaser, W. J.: Impact of woody encroachment on soil-plantherbivore interactions in the Kafue Flats floodplain ecosystem, $\mathrm{PhD}$ thesis, Swiss Federal Institute of Technology, ETH Zürich, Switzerland, 2013.

Bouillon, S., Yambélé, A., Gillikin, D. P., Teodoru, C., Darchambeau, F., Lambert, T., and Borges, A. V.: Contrasting biogeochemical characteristics of the Oubangui River and 
tributaries (Congo River basin), Scientific Reports, 4, 5402, doi:10.1038/srep05402, 2014.

Bronk, D. A., Lomas, M. W., Glibert, P. M., Schukert, K. J., and Sanderson, M. P.: Total dissolved nitrogen analysis: comparisons between the persulfate, UV and high temperature oxidation methods, Mar. Chem., 69, 163-178, 2000.

DelSontro, T., Kunz, M. J., Kempter, T., Wüest, A., Wehrli, B., and Senn, D. B.: Spatial Heterogeneity of Methane Ebullition in a Large Tropical Reservoir, Environ. Sci. Technol., 45, 9866-9873, doi:10.1021/es2005545, 2011.

Devol, A. H., Forsberg, B. R., Richey, J. E., and Pimentel, T. P.: Seasonal variation in chemical distributions in the Amazon (Solimões) River: A multiyear time series, Global Biogeochem. Cy., 9, 307-328, 1995.

Dunne, T., Mertes, L. A. K., Meade, R. H., Richey, J. E., and Forsberg, B. R.: Exchanges of sediment between the flood plain and channel of the Amazon River in Brazil, Geol. Soc. Am. Bull., 110, 450-467, 1998.

Ellenbroek, G. A.: Ecology and productivity of an African wetland system: The Kafue Flats, PhD thesis, Junk Publisher, Zambia, 1987.

Esser, G. and Kohlmaier, G. H.: Modelling terrestrial sources of nitrogen, phosphorus, sulphur, and organic carbon to rivers, in: Biogeochemistry of major world rivers, edited by: Degens, E. T., Kempe, S., and Richey, J. E., Wiley, Chichester, 297-322, 1991.

Fisher, J. and Acreman, M. C.: Wetland nutrient removal: a review of the evidence, Hydrol. Earth Syst. Sci., 8, 673-685, doi:10.5194/hess-8-673-2004, 2004.

Fu, K. D., He, D. M., and Lu, X. X.: Sedimentation in the Manwan reservoir in the Upper Mekong and its downstream impacts, Quartern. Int., 186, 91-99, 2008.

Hall, A., Valente, I. M. C. B. S., and Davies, B. R.: The Zambezi River in Mozambique: The physico-chemical status of the middle and lower Zambesi prior to closure of the Cabora Bassa Dam, Freshwater Biol., 7, 187-206, 1977.

Hamilton, S. K., Sippel, S. J., Calheiros, D. F., and Melack, J. M.: An anoxic event and other biogeochemical effects of the Pantanal wetland on the Paraguay River, Limnol. Oceanogr., 42, 257-272, 1997.

Harrison, J. A., Caraco, N., and Seitzinger, S. P.: Global patterns and sources of dissolved organic matter export to the coastal zone: Results from a spatially explicit, global model, Global Biogeochem. Cy., 19, GB4S04, doi:10.1029/2005gb002480, 2005.

Hedges, J. I., Clark, W. A., Quay, P. D., Richey, J. E., Devol, A. H., and Santos, U. D.: Compositions and fluxes of particulate organic material in the Amazon River, Limnol. Oceanogr., 31, 717-738, 1986.

Hughes, R. H. and Hughes, J. S.: A directory of African wetlands, UNEP, Nairobi \& IUCN, Gland Switzerland/WCMC, Cambridge, 1992.

Hunsinger, G. B., Mitra, S., Findlay, S. E. G., and Fischer, D. T.: Wetland-driven shifts in suspended particulate organic matter composition of the Hudson River estuary, New York, Limnol. Oceanogr., 55, 1653-1667, 2010.

Junk, W. J.: The flood pulse concept of large rivers: learning from the tropics, Large Rivers, 11, 261-280, 1999.

Junk, W. J. and Piedade, M. T. F.: Biomass and primary-production of herbaceous plant-communities in the Amazon floodplain, Hydrobiologia, 263, 155-162, doi:10.1007/bf00006266, 1993.
Junk, W. J., Bayley, P. B., and Sparks, R. E.: The flood pulse concept in river-floodplain systems in: Proceedings of the International Large River Symposium, edited by: Dodge, D. P., Canadian Special Publication of Fisheries and Aquatic Sciences, 106, 110-127, 1989.

Kummu, M. and Varis, O.: Sediment-related impacts due to upstream reservoir trapping, the Lower Mekong River, Geomorphology, 85, 275-293, doi:10.1016/j.geomorph.2006.03.024, 2007.

Kummu, M., Tes, S., Yin, S., Adamson, P., Józsa, J., Koponen, J., Richey, J., and Sarkkula, J.: Water balance analysis for the Tonle Sap Lake-floodplain system, Hydrol. Process., 28, 1722-1733, doi:10.1002/hyp.9718, 2014.

Kunz, M. J., Anselmetti, F. S., Wüest, A., Wehrli, B., Vollenweider, A., Thüring, S., and Senn, D. B.: Sediment accumulation and carbon, nitrogen, and phosphorus deposition in the large tropical reservoir Lake Kariba (Zambia/Zimbabwe), J. Geophys. Res., 116, G03003, doi:10.1029/2010jg001538, 2011a.

Kunz, M. J., Wüest, A., Wehrli, B., Landert, J., and Senn, D. B.: Impact of a large tropical reservoir on riverine transport of sediment, carbon, and nutrients to downstream wetlands, Water Resour. Res., 47, W12531, doi:10.1029/2011wr010996, $2011 \mathrm{~b}$.

Kunz, M. J., Senn, D. B., Wehrli, B., Mwelwa, E. M., and Wüest, A.: Optimizing turbine withdrawal from a tropical reservoir for improved water quality in downstream wetlands, Water Resour. Res., 49, 5570-5584, 2013.

Lewis Jr., W. and Saunders III, J.: Concentration and transport of dissolved and suspended substances in the Orinoco River, Biogeochemistry, 7, 203-240, doi:10.1007/BF00004218, 1989.

Lu, X. X. and Siew, R. Y.: Water discharge and sediment flux changes over the past decades in the Lower Mekong River: possible impacts of the Chinese dams, Hydrol. Earth Syst. Sci., 10, 181-195, doi:10.5194/hess-10-181-2006, 2006.

Maingi, J. K. and Marsh, S. E.: Quantifying hydrologic impacts following dam construction along the Tana River, Kenya, J. Arid Environ., 50, 53-79, doi:10.1006/jare.2000.0860, 2002.

Mariotti, A., Gadel, F., Giresse, P., and Kinga, M.: Carbon isotope composition and geochemistry of particulate organic matter in the Congo River (Central Africa): Application to the study of Quaternary sediments off the mouth of the river, Chem. Geol., 86, 345-357, 1991.

Mayorga, E., Seitzinger, S. P., Harrison, J. A., Dumont, E., Beusen, A. H. W., Bouwman, A. F., Fekete, B. M., Kroeze, C., and Van Drecht, G.: Global Nutrient Export from WaterSheds 2 (NEWS 2): Model development and implementation, Environ, Model, Softw,, 25, 837-853, doi:10.1016/j.envsoft.2010.01.007, 2010.

McJannet, D., Wallace, J., Keen, R., Hawdon, A., and Kemei, J.: The filtering capacity of a tropical riverine wetland: II. Sediment and nutrient balances, Hydrol. Process., 26, 53-72, doi:10.1002/hyp.8111, 2012.

Melack, J. M., Novo, E. M. L. M., Forsberg, B. R., Piedade, M. T. F., and Maurice, L.: Floodplain Ecosystem Processes, in: Amazonia and Global Change, edited by: Keller, M., Bustamente, M., Gash, J., and Silva Dias, P., Geoph. Monog. Series, American Geophysical Union, Washington, DC, 525-541, 2009.

Milliman, J. D. and Farnsworth, K. L.: River Discharge to the Coastal Ocean, Cambridge University Press, Cambridge, 2011.

Mulholland, P. J.: 6 - Large-Scale Patterns in Dissolved Organic Carbon Concentration, Flux, and Sources, in: Aquatic Ecosys- 
tems, edited by: Findlay, S. E. G. and Sinsabaugh, R. L., Academic Press, Burlington, 139-159, 2003.

Mumba, M. and Thompson, J. R.: Hydrological and ecological impacts of dams on the Kafue Flats floodplain system, southern Zambia, Phys. Chem. Earth, 30, 442-447, 2005.

Nilsson, C., Reidy, C. A., Dynesius, M., and Revenga, C.: Fragmentation and Flow Regulation of the World's Large River Systems, Science, 308, 405-408, doi:10.1126/science.1107887, 2005.

Pettit, N. E., Bayliss, P., Davies, P. M., Hamilton, S. K., Warfe, D. M., Bunn, S. E., and Douglas, M. M.: Seasonal contrasts in carbon resources and ecological processes on a tropical floodplain, Freshwater Biol., 56, 1047-1064, doi:10.1111/j.13652427.2010.02544.x, 2011.

Robertson, A. I., Bunn, S. E., Walker, K. F., and Boon, P. I.: Sources, sinks and transformations of organic carbon in Australian floodplain rivers, Mar. Freshwater Res., 50, 813-829, 1999.

Rood, S. B., Samuelson, G. M., Braatne, J. H., Gourley, C. R., Hughes, F. M. R., and Mahoney, J. M.: Managing river flows to restore floodplain forests, Front. Ecol. Environ., 3, 193-201, doi:10.1890/1540-9295(2005)003[0193:MRFTRF]2.0.CO;2, 2005.

Rudorff, C. M., Melack, J. M., and Bates, P. D.: Flooding dynamics on the lower Amazon floodplain: 2. Seasonal and interannual hydrological variability, Water Resour. Res., 50, 635-649, doi:10.1002/2013WR014714, 2014.

Ruttenberg, K. C.: Development of a sequential extraction method for different forms of phosphorus in marine sediments, Limnol. Oceanogr., 37, 1460-1482, 1992.

Slomp, C. P., Epping, E. H. G., Helder, W., and Van Raaphorst, W.: A key role for iron-bound phosphorus in authigenic apatite formation in North Atlantic continental platform sediments, J. Mar. Res., 54, 1179-1205, 1996.

Solórzano, L. and Sharp, J. H.: Determination of total dissolved nitrogen in natural waters, Limnol. Oceanogr., 25, 751-754, 1980.

Spencer, R. G. M., Hernes, P. J., Ruf, R., Baker, A., Dyda, R. Y., Stubbins, A., and Six, J.: Temporal controls on dissolved organic matter and lignin biogeochemistry in a pristine tropical river, Democratic Republic of Congo, J. Geophys. Res.-Biogeo., 115, G03013 doi:10.1029/2009jg001180, 2010.

Tamooh, F., Meysman, F. J. R., Borges, A. V., Marwick, T. R., Van Den Meersche, K., Dehairs, F., Merckx, R., and Bouillon, S.: Sediment and carbon fluxes along a longitudinal gradient in the lower Tana River (Kenya), J. Geophys. Res.-Biogeo., 119, 13401353, doi:10.1002/2013JG002358, 2014.
Timberlake, J.: Biodiversity of the Zambezi basin, Occasional publications in biodiversity No. 9, Bulawayo,Biodiversity Foundation for Africa, Zimbabwe, 2000.

Tockner, K. and Stanford, J. A.: Riverine flood plains: present state and future trends, Environ. Conserv., 29, 308-330, doi:10.1017/s037689290200022x, 2002.

Tockner, K., Pusch, M., Borchardt, D., and Lorang, M. S.: Multiple stressors in coupled river-floodplain ecosystems, Freshwater Biol., 55, 135-151, doi:10.1111/j.1365-2427.2009.02371.x, 2010.

Villar, C. A., de Cabo, L., Vaithiyanathan, P., and Bonetto, C.: River-floodplain interactions: nutrient concentrations in the Lower Parana River, Arch Hydrobiol., 142, 433-450, 1998.

Wamulume, J., Landert, J., Zurbrügg, R., Nyambe, I., Wehrli, B., and Senn, D. B.: Exploring the hydrology and biogeochemistry of the dam-impacted Kafue River and Kafue Flats (Zambia), Phys. Chem. Earth Parts A/B/C, 36, 775-788, doi:10.1016/j.pce.2011.07.049, 2011.

Ward, J. V. and Stanford, J. A.: The serial discontinuity concept: extending the model to floodplain rivers, Regul. River, 10, 159$168,1995$.

Wiegner, T. N., Tubal, R. L., and MacKenzie, R. A.: Bioavailability and export of dissolved organic matter from a tropical river during base- and stormflow conditions, Limnol. Oceanogr., 54, 1233-1242, doi:10.4319/lo.2009.54.4.1233, 2009.

Zambezi Society: Biodiversity of the Zambezi Basin Wetlands: Volume III: Land use change and human impacts, Zambezi Society and Biodiversity Foundation for Africa, 2000.

Zurbrügg, R., Wamulume, J., Kamanga, R., Wehrli, B., and Senn, D. B.: River-floodplain exchange and its effects on the fluvial oxygen regime in a large tropical river system (Kafue Flats, Zambia), J. Geophys. Res., 117, G03008, doi:10.1029/2011jg001853, 2012.

Zurbrügg, R., Suter, S., Lehmann, M. F., Wehrli, B., and Senn, D. B.: Organic carbon and nitrogen export from a tropical dam-impacted floodplain system, Biogeosciences, 10, 23-38, doi:10.5194/bg-10-23-2013, 2013. 